\title{
Relationship between serum leptin levels, non-cardiovascular risk factors and mortality in hemodialysis patients
}

\author{
IVONA RISOVIC ${ }^{1,2}$, VLASTIMIR VLATKOVIC ${ }^{2,3}$, SNJEZANA POPOVIC-PEJICIC ${ }^{1,2}$, GABRIJELA MALEŠEVIĆ $^{1,2}$ \\ ${ }^{1}$ Department of Endocrinology, University Clinical Center of the Republic of Srpska, 12 babies nn, Banja Luka, Bosnia and Herzegovina, \\ ${ }^{2}$ Faculty of Medicine, University of Banja Luka, Save Mrkalja 14, Banja Luka, Bosnia and Herzegovina, \\ ${ }^{3}$ Department of Nephrology, University Clinical Center of the Republic of Srpska, 12 babies nn, Banja Luka, Bosnia and Herzegovina
}

\begin{abstract}
Introduction. Hemodialysis (HD) patients have higher mortality rate than the general population. Recent studies indicate a significant role of non-cardiovascular risk factors in for mortality in HD patients. Leptin is protein hormone and may indicate malnutrition in HD patients. Its role in mortality in these patients is being examined. This study aimed to investigate the correlation between serum leptin levels and non-cardiovascular risk factors and relationship between leptin level and mortality in HD patients.

Methods. The prospective study included 93 patients on maintenance HD and follow-up period was 12 months. We measured leptin level and evaluated non-cardiovascular risk factors: nutritional status, anemia, volemia, parameters of mineral and bone disorder.

Results. Out of 93 patients 9 died during study and 1 underwent kidney transplantation. Malnutrition and hypervolemia were two main non-cardiovascular risk factors among deceased subjects. Leptin showed a significant direct correlation with nutritional BMI $(\mathrm{r}=0.72, P<0.001)$, fat tissue index $(\mathrm{r}=0.74, P<0.001)$ and statistically significant inverse correlation with leantissue index $(\mathrm{r}=-0.349, P<0.05)$ and inverse correlation with volemic parameters (overhydration / extracellular water ratio $(\mathrm{r}=-0.38, P<0.001)$, but no association with anemia and mineral bone parameters was observed. Elevated leptin levels were associated with better survival. However, no statistically significant difference in survival rates was observed between the study groups (Log-Rank $P=0.214$, Breslow $P=0.211$, Tarone-Ware $P=0.212$ ).

Conclusion. Deceased patients had significantly lower leptin values. Leptin was associated with two non-cardiovascular risk factors for mortality: malnutrition and hypervolemia.
\end{abstract}

Key words: leptin, hemodialysis, risk factors, mortality, malnutrition, volemia.

\section{What is new? What is important?}

To pay more attention to non-cardiovascular risk factor and try to correct them. Low leptin level could predict worse outcome in hemodialysis patients

\section{INTRODUCTION}

Improvements in the quality of treatment and dialysis technologies have significantly contributed to the quality of life and survival of patients on hemodialysis (HD) [1]. However, the mortality rate of these patients is still high, from $10-25 \%$ relative to the general population. Cardiovascular disease is still a major cause of morbidity and mortality in patients on HD $[1,2]$. In addition to traditional cardiovascular risk factors, recent studies indicate the importance of nontraditional non-cardiovascular risk factors for morbidity and mortality in HD patients, and the fact that these causes have been underestimated so far $[1,3]$. In the recent time more importance is being given to factors that result from uremia, i.e. non-cardiovascular risk factors such as hypervolemia, malnutrition, anemia, insulin resistance, hyperphosphatemia, calcium and phosphate products, inflammation, endothelial dysfunction [3]. Uremic metabolite accumulation, metabolic acidosis, inflammation, and comorbidities all contribute to appetite suppression, catabolism, and malnutrition in HD patients. Restrictive diet to balance serum potassium and phosphate contribute to malnutrition [4]. Hemodialysis patients have constant variations in volemic status, with frequent weight gain between hemodialysis. These results result in constant volume loading, problems in determining and achieving dry weight, changes in body composition, numerous complications lead to poor outcome in hemodialysis patients [5]. In the late 1990s, inflammation was recognized as an essential part of chronic kidney disease, and an important risk factor for HD morbidity 
and mortality [6]. Anemia is one of the complications of chronic kidney disease. Primarily due to a decrease in erythropoietin synthesis in the kidney, blood loss during the dialysis process and impaired appetite further contribute to anemia [7, 8]. Mineral and bone metabolism disorders are often present in hemodialysis patients. Studies have shown that elevated calcium, phosphate and parathyroid hormone (PTH) levels are associated with all mortality patterns [9].

Leptin is a protein hormone, with a molecular weight of $16 \mathrm{kDa}$, made up of 167 amino acids, which is largely synthesized in adipocytes of subcutaneous white adipose tissue and in: brown adipose tissue, bone marrow, placenta, stomach, ovaries, skeletal muscle, pituitary and liver. It is excreted by the kidneys $[10,11]$. The primary role of leptin is to participate in the regulation of food intake and energy consumption. In HD patients, leptin levels are elevated due to decreased renal excretion $[11,12]$. Leptin is involved in the regulation of appetite and might have a role in the development of anorexia in uremia $[5,13]$. Studies in HD patients have shown that leptin values correlate with nutritional status, and that leptin may indicate malnutrition in these patients [13]. There are still different results regarding the effect of leptin on survival in HD patients.

The aim of this study was to investigate the correlation between leptin levels and non-cardiovascular risk factors: nutritional status, anemia, volemia, parameters of mineral and bone disorder and relationship between leptin level and mortality in chronic HD patient.

\section{MATERIALS AND METHODS}

This prospective study included 93 patients (55 men and 38 women) on maintenance HD in the International Dialysis Center (Laktasi, Bosnia and Herzegovina). The follow-up period was 12 months, from January 2016 to January 2017. It was carried out according to the principles of the Declaration of Helsinki and was approved by the Ethical Board of the University Clinical Center of the Republic of Srpska. All biochemical analyses were performed in the "Konzilijum" laboratory. Venous blood samples were drawn before the mid-week HD session. Analyses were performed at baseline and after 12 months of follow up. The following parameters were measured in serum: leptin, hemoglobin, albumin, $\mathrm{C}$ reactive protein (CRP), ferritin, iron, calcium, phosphate, intact parathyroid hormone (iPTH) and calculated calcium and phosphate product. Leptin was determined using the enzyme-linked immunosorbent assay (ELISA).
Serum albumin, iron, CRP, ferritin, calcium, phosphate, iPTH were all determined using the AU 680 Olympus machine by spectrophotometry, immunoturbidimetric, and immunochemiluminescent assays, respectively. Serum hemoglobin was determined on the Advia 2120 machine by cytometric peroxidase. The BMI was calculated using the Quetelet formula: BMI = body weight $(\mathrm{kg}) /$ height $\left(\mathrm{m}^{2}\right)$. Overhydration/extracellular water ratio $(\mathrm{OH} / \mathrm{ECW})$, lean tissue index (LTI), and fat tissue index (FTI) were measured using multifrequency bioimpedance (Body Composition Monitor [BCM], Fresenius Medical Care, Bad Homburg, Germany). All measurements were taken before the mid-week HD session, in the supine position, after 2 min of rest. All patients were on high-flux dialysis using the polysulfone CorDiax membranes. Dialysis adequacy was assessed using the single-pool Kt/V and online clearance monitoring (OCM) module. Exclusion criteria were less than 3 months of dialysis vintage, fewer than three HD weekly, corticosteroid and immunosuppressive therapy, thyroid dysfunction, acute inflammation, malignancy $[4,13]$. The underlying renal diseases were chronic pyelonephritis $(27.9 \%)$, diabetic nephropathy $(22.6 \%)$, glomerulonephritis (14\%), cystic renal disease (11.8\%), renovascular disease $(6.5 \%)$, and other renal diseases (17.2\%). Eighty patients (86\%) had Brescia-Cimino arteriovenous fistulas as vascular access, one (1\%) had PTFE graft, four (4.3\%) had permanent and eight $(8.7 \%)$ had temporary central venous catheters. At the time of patients enrolment, the mean duration of time on HD treatment was $84.72 \pm 62.60$ months. The shortest time on HD was 5 months and the longest was 361 months. Most patients underwent dialysis less than 5 years $(44.1 \%), 5$ to 10 years $31.2 \%, 10$ to 15 years $18.3 \%$, and $6.4 \%$ of patients longer than 15 years. Of the 93 patients, 9 had diabetes mellitus $(9.67 \%), 5$ were women $(5.37 \%)$ and 4 men (4.30\%), with no statistical significance $(P>0.05)$.

\section{Statistical analysis}

Continuous variables were described by means and standard deviations. Normality of distribution of the datasets was assessed using the KolmogorovSmirnov test. To compare means of continuous variables with normal distribution, we used the Student's t-test for independent samples or analysis of variance (ANOVA) in cases of more than two independent samples. The F-test was used to compare variances of continuous variables in independent samples. The Mann-Whitney or Kruskall-Wallis test was used for comparison of nonparametric data as appropriate. Repeated measurements were analyzed 
by the Student's t-test for paired samples in case of normal distribution, Wilcoxon test for variables with non-normal distribution, or Friedman test for more than two data groups with non-normal distribution. Correlation between the observed variables was assessed using the Spearman non parametric rankorder test. Statistical significance was defined at the 95\% level $(\mathrm{P}<0.05)$. The Kaplan-Meier method, log rank, Breslow and Tarone - Ware tests are used for survival analysis. All analyses were carried out using the IBM SPSS Statistics 21.0 (IBM Corp, Armonk, NY, USA).

\section{RESULTS}

At the end of the one-year study, the outcome was as follows: 83 patients survived (of which 39 were women and 48 were men), 9 died during the study period, and 1 patient underwent kidney transplantation. Men were more likely to have a fatal outcome than women, but this is not statistically significant. Table 1 shows the demographic, clinical and laboratory data of the subjects. Patients with low leptin level had low BMI, FTI,LMI, higher ferritin and CRP, $\mathrm{P}<0.05$, Table 2 .

Table 1

Demographic and laboratory data

\begin{tabular}{|l|c|c|c|c|}
\hline \multicolumn{1}{|c|}{ Parameter } & \multicolumn{2}{c|}{ Alive patients } & Deceased patients & P value \\
Age (years) & Baseline & After 12 month & $71.1 \pm 9.32$ & $<0.05$ \\
Dialysis vintage (months) & $64.27 \pm 13.20$ & $74.33 \pm 11.15$ & $87.30 \pm 58.76$ & $\mathrm{~ns}$ \\
BMI, kg/m & $84.94 \pm 63.99$ & $94.21 \pm 55.12$ & $21.58 \pm 3.50$ & $<0.05$ \\
Leptin, ng/ml & $25.04 \pm 4.26$ & $24.83 \pm 4.32$ & $5.09 \pm 8.25$ & $<0.001$ \\
Albumin, g/l & $28.46 \pm 36.97$ & $29.8 \pm 37.8$ & $38.70 \pm 2.56$ & $\mathrm{~ns}$ \\
CRP $(\mathrm{mg} / \mathrm{l})$ & $41.16 \pm 3.23$ & $42.23 \pm 4.21$ & $7.58 \pm 0.16$ & $\mathrm{~ns}$ \\
Ferritin $(\mathrm{ng} / \mathrm{ml})$ & $6.85 \pm 3.9$ & $6.19 \pm 2.58$ & $780.30 \pm 340.80$ & $<0.001$ \\
Hemoglobin $(\mathrm{g} / \mathrm{l})$ & $575.84 \pm 317.08$ & $584.04 \pm 360.92$ & $112.59 \pm 12.41$ & $\mathrm{~ns}$ \\
Iron $(\mu \mathrm{mol} / \mathrm{l})$ & $113.30 \pm 16.33$ & $114.40 \pm 9.83$ & $13.75 \pm 5.27$ & $\mathrm{~ns}$ \\
FTI $\left(\mathrm{kg} / \mathrm{m}^{2}\right)$ & $13.72 \pm 5.02$ & $12.02 \pm 4.57$ & $9.30 \pm 4.75$ & $<0.05$ \\
LTI $\left(\mathrm{kg} / \mathrm{m}^{2}\right)$ & $12.60 \pm 5.29$ & $12.76 \pm 5.29$ & $11.38 \pm 2.79$ & $\mathrm{~ns}$ \\
OH/ECW $(\%)$ & $12.24 \pm 2.85$ & $12.12 \pm 7.28$ & $19.26 \pm 3.83$ & $<0.05$ \\
Ca $(\mathrm{mmol} / \mathrm{l})$ & $13.64 \pm 9.61$ & $13.94 \pm 8.58$ & $2.32 \pm 0.11$ & $\mathrm{~ns}$ \\
P $(\mathrm{mmol} / \mathrm{l})$ & $2.30 \pm 0.17$ & $2.40 \pm 0.14$ & $1.36 \pm 0.45$ & $<0.05$ \\
iPTH $\left(\mathrm{pg} / \mathrm{ml}^{2}\right)$ & $1.24 \pm 0.36$ & $1.35 \pm 0.34$ & $415.12 \pm 48.95$ & $<0.05$ \\
CaxP $\left(\mathrm{mmol} / \mathrm{l}^{2}\right)$ & $334.96 \pm 41.08$ & $344.65 \pm 53.80$ & $3.12 \pm 0.03$ & $\mathrm{~ns}$ \\
OCM & $2.30 \pm 0.17$ & $2.40 \pm 0.14$ & $1.41 \pm 0.1$ & $\mathrm{~ns}$ \\
\hline
\end{tabular}

Data are presented as mean \pm SD. BMI - Body Mass Index, HDL - high density lipoprotein, LDL - low density lipoprotein, CRP $\mathrm{C}$-reactive protein, OCM - Online Clearens Monitoring, OH/ECW - overhydration/extracellular water ratio, LTI - lean tissue index, FTI - fat tissue index, $\mathrm{Ca}$ - calcium, $\mathrm{P}$ - phosphate, iPTH - intact parathyroid hormone, CaxP - calcium and posphate product.

Table 2

Demographic and laboratory data according to baseline leptin level

\begin{tabular}{|c|c|c|c|c|}
\hline Parameter & Low leptin level & Normal leptin level & High leptin level & $P$ value \\
\hline Age (years) & $76.13 \pm 10.50$ & $74.21 \pm 8.56$ & $72.14 \pm 11.54$ & ns \\
\hline Dialysis vintage (months) & $86.12 \pm 22.56$ & $85.47 \pm 36.12$ & $84.12 \pm 34.41$ & ns \\
\hline $\mathrm{BMI}, \mathrm{kg} / \mathrm{m}^{2}$ & $19.09 \pm 1.24$ & $22.83 \pm 2.72$ & 27.92 .3 .80 & $<0.001$ \\
\hline Albumin, $\mathrm{g} / \mathrm{l}$ & $36.36 \pm 3.42$ & $41.02 \pm 2.78$ & $41.66 \pm 3.11$ & $<0.001$ \\
\hline CRP (mg/l) & $10.13 \pm 6.45$ & $7.88 \pm 11.59$ & $6.94 \pm 8.14$ & $<0.001$ \\
\hline Ferritin (ng/ml) & $865.22 \pm 407.89$ & $590.88 \pm 277.06$ & $524.00 \pm 283.12$ & $<0.05$ \\
\hline Hemoglobin (g/l) & $106.56 \pm 14.09$ & $110.93 \pm 14.93$ & $115.63 \pm 9.58$ & ns \\
\hline Iron $(\mu \mathrm{mol} / \mathrm{l})$ & $12.96 \pm 5.60$ & $12.98 \pm 4.65$ & $14.20 \pm 5.12$ & ns \\
\hline FTI $\left(\mathrm{kg} / \mathrm{m}^{2}\right)$ & $7.56 \pm 3.01$ & $9.61 \pm 3.51$ & $16.20 \pm 4.51$ & $<0.001$ \\
\hline LTI $\left(\mathrm{kg} / \mathrm{m}^{2}\right)$ & $10.43 \pm 2.12$ & $11.73 \pm 2.75$ & $12.83 \pm 3.00$ & $<0.05$ \\
\hline $\mathrm{OH} / \mathrm{ECW}(\%)$ & $16.60 \pm 8.51$ & $13.52 \pm 3.12$ & $13.06 \pm 8.51$ & $<0.05$ \\
\hline $\mathrm{Ca}(\mathrm{mmol} / \mathrm{l})$ & $2.27 \pm 0.17$ & $2.31 \pm 0.16$ & $2.29 \pm 0.18$ & ns \\
\hline $\mathrm{P}(\mathrm{mmol} / \mathrm{l})$ & $1.18 \pm 0.33$ & $1.27 \pm 0.40$ & $1.12 \pm 0.33$ & ns \\
\hline iPTH (pg/ml) & $519.67 \pm 997.42$ & $344.56 \pm 360.62$ & $284.34 \pm 206.77$ & $<0.001$ \\
\hline $\operatorname{CaxP}\left(\mathrm{mmol}^{2} / \mathrm{l}^{2}\right)$ & $2.69 \pm 0.05$ & $2.93 \pm 0.06$ & $2,56 \pm 0.05$ & ns \\
\hline $\mathrm{OCM}$ & $1.79 \pm 0.23$ & $1.60 \pm 0.27$ & $1.65 \pm 0.26$ & ns \\
\hline
\end{tabular}

Data are presented as mean \pm SD. BMI - Body Mass Index, HDL - high density lipoprotein, LDL - low density lipoprotein, CRP C-reactive protein, OCM - Online Clearens Monitoring, OH/ECW - overhydration/extracellular water ratio, LTI - lean tissue index, FTI - fat tissue index, $\mathrm{Ca}$ - calcium, $\mathrm{P}$ - phosphate, $\mathrm{iPTH}$ - intact parathyroid hormone, CaxP - calcium and posphate product. 
The most common cause of mortality was cardiovascular disease. Observing non-cardiovascular risk factors, deaths was associated with malnutrition, hypervolemia, inflammation, anemia, mineral and bone disorder, Figure 1. Six patients had 2 noncardiovascular risk factors simultaneously, 2 patients had 1 risk factor, and 1 patient had 3 risk factors.

Examining the association between leptin and non-cardiovascular risk factors, it was found that there was a significant direct correlation between leptin with: $\mathrm{BMI}(\mathrm{r}=0.72, P<0.001)$, fat tissue index $(\mathrm{r}=0.74, P<0.001)$ and statistically significant inverse correlation between leptin with lean tissue index $(\mathrm{r}=-0.349, P<0.05)$ and overhydration / extracellular water ratio $(\mathrm{r}=-0.38, P<0.001)$.

Patients who survived the study had significantly leptin level higher than in the patients who died during the study, $P<0.001$. Viewed according to the leptin reference values, patients with increased leptin values had the highest chances of survival, and the patients with decreased leptin level had the least chance of survival. However, the difference in survival between the study groups with respect to patients' leptin values was not statistically significant at any stage of the study (Log-Rank $P<0.214$, Breslow $P<0.211$, Tarone-Ware $P<0.212$ ), Figure 2 .

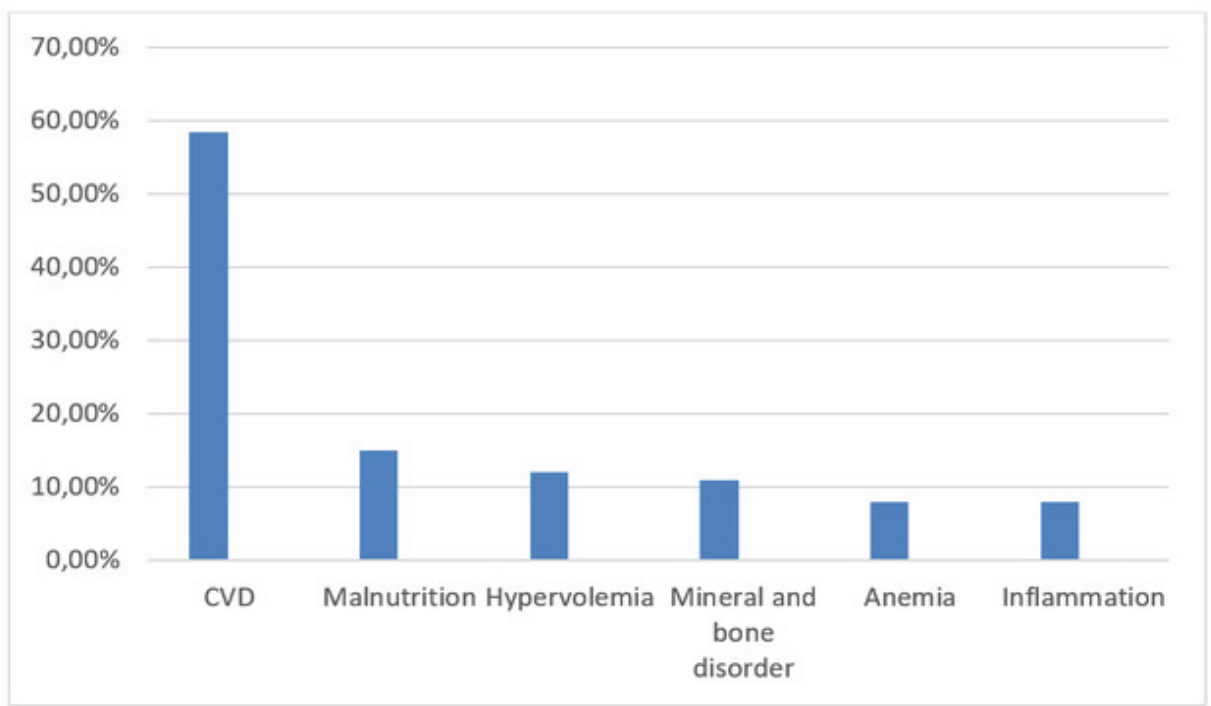

Figure 1. Causes of mortality in percentage. Malnutrition and hypervolemia were main non-cardiovascular risk factors for moratlity.

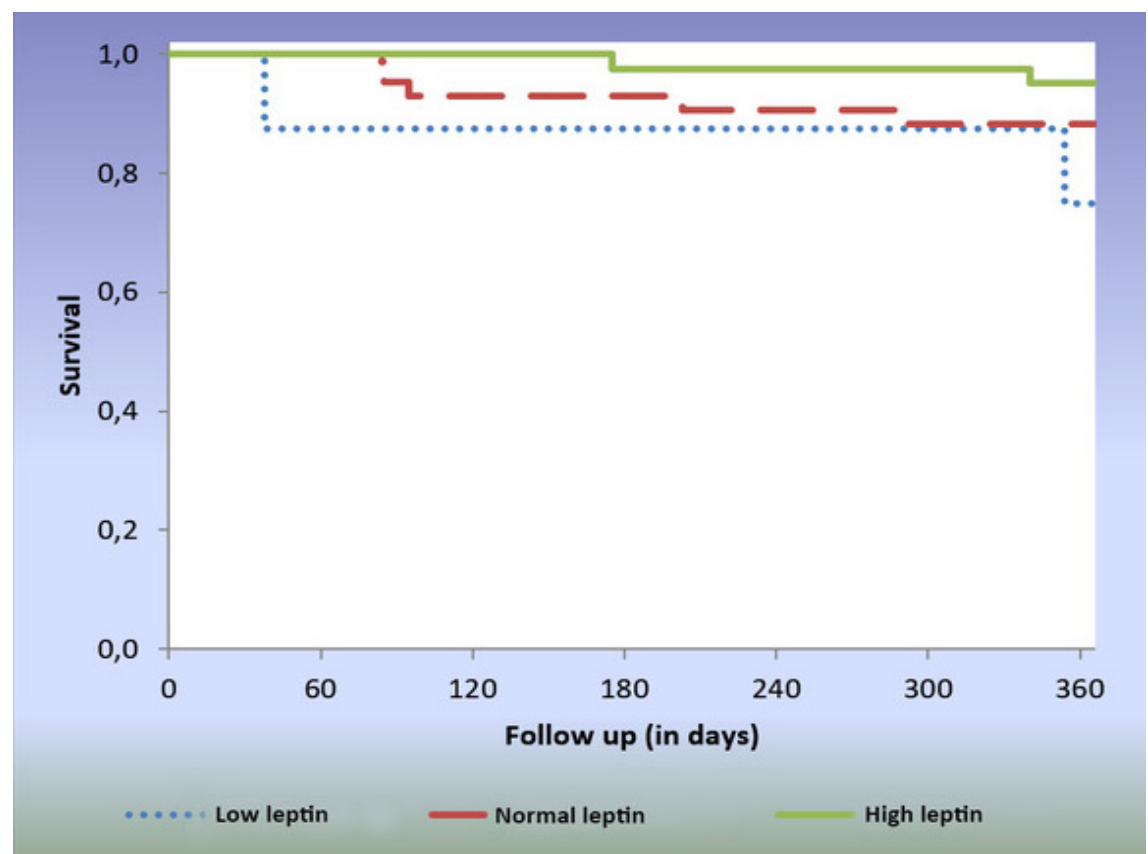

Figure 2. Kaplan-Meier survival curve. High leptin levels were associated with better survival. The subjects who died had significantly lower leptin levels than the survivors. However, no statistically significant difference in survival rates was observed in the study group. 


\section{DISCUSSIONS}

The mortality rate in HD patients is still higher than in the general population. Although cardiovascular risk factors are the most common cause of mortality in these patients, recent studies indicate a significant role of non-cardiovascular risk or uremia-related factors and they are insufficiently examined $[1,3]$.

The overall mortality rate of our patients was $10.3 \%$, which coincides with the mortality rate in Europe. The cardiovascular mortality rate was $56 \%$ and non-cardiovascular mortality rate was $44 \%$ (malnutrition 13\%, hypervolemia $11 \%$, mineral and bone disorder $10 \%$, anemia $5 \%$, inflammation $5 \%$ ). Similar to other authors' data, cardiovascular disease was the most common cause of mortality in our subjects $[1,3]$.

Systemic inflammation in HD patients may be related to the presence of central venous catheters, which is associated with infectious complications. Since $13 \%$ of patients in the study population had central venous catheters these could be one of the reason for higher inflammatory parameter in deceased patients. We founded that complication of vascular access were associated with more frequent hospitalizations and 2 deceased patients had central venous catheters. We could suggest that central venous catheters could be surrogate marker of sicker patients who are more likely to die.

In our study, the deceased patients were older than the living patients, they had a lower nutritional status and decreased leptin levels, they had an increased inflammation parameter and were hypervolemic. In hemodialysis patients, overhydration is associated with malnutrition and inflammation, representing a strong predictor of all-cause mortality in this population $[3,5,14-16]$. Malnutrition and inflammation often occur together and overlap, and these two entities in HD patients are viewed together as a malnutrition and inflammation complex syndrome [17]. Poor nutrition and inflammation indicate the presence of malnutrition inflammation complex syndrome in our deceased patients. Abnormalities in mineral homeostasis are common in patients with end stage renal disease and are associated with numerous adverse outcomes including vascular calcification, inflammation and mortality. There are also significant difference in phosphate and iPTH level between observed groups. Several observational studies have shown an association between deranged markers of mineral and bone disorder, and poor clinical outcomes in both predialysis and dialysis patients [9, 18]. Serum albumin is a known marker of malnutrition, and it is also recognized as a marker of inflammation because it is an acute phase reactant. Hypoalbuminemia in HD patients has been described as a risk factor for poor prognosis $[19,20]$. In our study we didn't noticed in serum albumin level in observed group.

Examination of non-cardiovascular cause of mortality revealed that malnutrition and hypervolemia are the two most common factors. The results of other authors have shown that malnutrition, inflammation and anemia are the factors most commonly associated with mortality in HD patients [14-16].

In our study leptin showed an association with nutritional and volemic parameters, but no association with anemia and mineral bone parameters was observed. Our results showed that nutritional, volume and inflammation status change with leptin level. We found similar results with other authors $[5,15,16,21]$. Several studies have shown decreased leptin levels in severely malnourished dialysis patients $[5,13,21]$. Variations in volume status are accompanied by changes in body composition as hypervolemia is often associated with loss of muscle and fat tissue and this maybe could explain relationship between leptin and volume status $[5,16]$. However, some authors have observed a correlation between leptin with age, albumin levels [22, 23].

Examining the effect of leptin on survival in our subjects, it was observed that elevated leptin values were associated with better survival. The patients who died had significantly lower leptin levels than the survivors. However, no statistically significant difference in survival rates was observed between the study groups. For now, leptin is known as an indicator of the nutritional status in HD patients [22]. The higher survival rate of patients with higher leptin levels could be explained by the term "reverse epidemiology". In patients with end-stage renal disease, it has been observed that individuals with a higher BMI have a higher survival rate and this phenomenon has been described as "paradoxical obesity" or "reverse epidemiology" $[23,24]$. Other authors' studies of the effect of leptin on survival rate in HD patients are conflicting. One group of researchers has shown that reduced leptin levels is independent predictor of mortality in hemodialysis patients $[2,25]$. Contrary to these results, some authors did not observe the effect of leptin on mortality in hemodialysis patients [13].

\section{CONCLUSION}

The deceased patients had significantly lower leptin level. Leptin was associated with the two most prevalent non-cardiovascular risk factors for mortality: malnutrition and hypervolemia. 
Introducere. Pacienții cu hemodializă (HD) au o rată a mortalității mai mare comparativ cu populația generală. Studiile recente au arătat un rol semnificativ al factorilor de risc non-cardiovasculari. Leptina este un hormon care ar indica malnutriția la pacienții cu HD. Studiul își propune să investigheze asocierea dintre nivelurile serice ale leptinei și mortalitatea la pacienții cu HD.

Metode. Au fost incluși 93 de pacienți cu HD urmăriți o perioadă de 18 luni. A fost măsurată leptina și s-au evaluat următorii factori de risc noncardiovasculari: statusul nutrițional, volemia, parametri echilibrului fosfocalcic.

Rezultate. 9 pacienți au decedatși 1 pacient a fost transplantat renal. Malnutriția și hipervolemia au fost cei doi factori non-cardiovasculari importanți prezenți la pacienții decedați. Leptina s-a corelat cu BMI $(r=0,72, P<0,001)$, indexul adipos $(r=0,74, P<0,001)$ și hiperhidratarea $(r=-0,38, P<0,001) . N u$ $s$-au observat corelații cu parametri metabolismului fosfocalcic. Deși nivelurile crescute ale leptinei au fost mai mari la pacienții supraviețitori, nu s-a observat o diferență semnificativă statistic intre curbele de supraviețuire (Log-Rank $P=$ 0,214).

Concluzii. Pacienții decedați au avut niveluri mai mici ale leptinei. Leptina s-a asociat cu malnutriția și hipervolemia.

Correspondence to: Ivona Risovic, MD, PhD, 12 babies nn 78000 Banja Luka, Bosnia and Herzegovina E-mail: ivona.risovic@gmail.com Phone: + 38765327897

Acnowledgements: none to declare.

Conflict of interest disclosure: The autors declare that there are not conflicts of interest.

\section{REFERENCES}

1. CHANDRASHEKAR A, RAMAKRISHNAN S, RANGARJAN D. Survival analysis of patients on maintenance hemodialysis. Indian J Nephrol. 2014; 24(4):206-13. doi: 10.4103/0971-4065.132985.

2. SCHOLZE A, RATTENSPERGER D, ZIDEK W, TEPEL M. Low serum leptin predicts mortality in patients with chronic kidney disease stage 5. Obesity 2007; 15(6): 1617-22. doi: 10.1038/oby.2007.191.

3. SAMEIRO-FARIA MD, RIBEIRO S, COSTA E, MENDONCA D, TEXEIRA L et al. Risk factors for mortality in hemodialysis patients: two-year follow-up study. Dis Markers. 2013;35(6):791-8. Do i: 10.1155/2013/518945.

4. PALMER SC,RUOSPO M, CAMPBELL KL, GARCIA ALERSEN V, SAGLIMBENE V et al. Nutrition and dietary, intake and their association with mortality and hospitalisation in adults with chronic kidney disease treated with haemodialysis: protocol for DIET-HD, a prospective multinational cohort study. BMJ Open 2015;5:e006897.doi:10.1136/bmjopen-2014-006897.

5. RISOVIĆ I, VLATKOVIĆ V, POPOVIĆ-PEJIČIĆ S, TRBOJEVIĆ-STANKOVIĆ J. The relationship between leptin level, inflammation and volume status in maintenance hemodialysis patient. Ther Apher Dial 2019; 23(1):59-64. doi: 10.1111/17449987.12750.

6. ACHINGER SG, AYUS JC. Inflammation from dialysis, can it be removed? Nephrol Dial Transplant 2013; 28 (4): 770-3. doi: $10.1093 / \mathrm{ndt} / \mathrm{gfs} 480$.

7. BROOKHART MA, SSHNEEWEISS S, AVORN J, BRADBURY BD, LIU J, WINKELMAYER WC. Comparative Mortality Risk of Anemia Management Practices in Incident Hemodialysis Patients. JAMA. 2010; 303(9):857-64. doi:10.1001/jama.2010.206.

8. KDIGO clinical pracitice guideline for Anemia in Chronic Kidney Disease. Kidney Int 2012; 2:279-335.

9. FULLER DS, DLUZNIEWSKI PJ, COOPER K, BRADBURY BD, ROBINSON BM,TENTORI F. Combinations of mineral and bone disorder markers and risk of death and hospitalizations in the international Dialysis Outcomes and Practice Patterns Study, Clin Kidney J, sfz112, doi: 10.1093/ckj/sfz112.

10. KELESIDIS T, KELESIDIS I, CHOU S, MANTZOROS C. Narrative review: the role of leptin in human physiology:emerging clinical applications. Ann Intern Med 2010; 152(2):93-100. doi:10.1059/0003-4819-152-2-201001190-0000.

11. FRIEDMAN J. Leptin at 20: an overiew. J Endocrinol 2014; 223:1-8. doi. 10.1530/JOE-14-0405.

12. PARK HY, AHIMA RS. Physiology of leptin: energy homeostasis, neuroendocrine function and metabolism. Metabolism 2015; 64(1):24-6. doi: 10.1016/j.metabol.2014.08.004.

13. BUENO DE OLIVERA R, LIABEUF S, OKAZAKI H, LENGLET A, DESJARDINSZ L et al. The clinical impact of plasma leptin levels in a cohort of chronic kidney disease patients. Clin Kidney J 2013; 6: 63-70. doi: 10.1093/ckj/sfs 176 
14. MA L, ZHAO S. Risk factors for mortality in patients undergoing hemodialysis: A systematic review and meta-analysis. Int $J$ Cardiol. 2017; 238:151-58. doi:10.1016/j.ijcard.2017.02.095

15. KURAGANO T, MATSUMURA O, MATSUDA A, HARA T, KIYOMOTO H et al. Association between hemoglobin variability, serum ferritin levels, and adverse events/mortality in maintenance hemodialysis patients. Kidney Int. 2014; 86: 84554 doi: $10.1038 / \mathrm{ki} .2014 .114$

16. ANTALAGER M, HECKING M, HALDINGER M, WERZOWA J, KOVARIK JJ et al. Fluid overload in hemodialysis patients: a cross-sectional study to determine its association with cardiac biomarkers and nutritional status. BMC Nephrol 2013;2:266 doi: 10.1186/1471-2369-14-266

17. KALANTAR-ZADEH K, IKLIZER TA, BLOCK G, AVRAM MM, KOPPLE JD. Malnutrition inflammation complex syndome in dialysis patients: causes and consequences. Am J Kidney Dis 2003; 4(5); 864-8. doi: 10.1016/j.ajkd.2003.07.016

18. WAZIRI B, DUARTE R, NAICKER S. Chronic Kidney Disease-Mineral and Bone Disorder (CKD-MBD): Current Perspectives. Int J Nephrol Renovasc Dis. 2019. 24; 12:263-76. doi: 10.2147/IJNRD.S191156.

19. DON BR, KAYSEN G. Serum albumin: relationship to inflammation and nutrition. Semin Dial. 2004; 17:432-7. doi: 10.1111/ j.0894-0959.2004.17603.x.

20. SRIDHAR NR, JOSULA S. Hypoalbuminemia in hemodialyzed end stage renal disease patients: risk factors and relationships-a 2 year single center study. BMC Nephrol. 2013; 14:242-49. doi:10.1186/1471-2369-14-242

21. AHAMADI F, BOSOSRGEMEHR R, RAZEGHI E. Relationship between serum leptin level and laboratory and anthropometric indices of malnutrition in patients on hemodialysis. Indian J Nephrol 2008;18 (3): 105-11 doi: 10.4103/0971-4065.43689

22. YILMAZ A, KAYARDI M, ICOGASIOGLU S, CANDAN F, NUR N, GULTEKIN F. Relationship between serum leptin levels and body composition and markers of malnutrition in nondiabetic patients on peritoneal dialysis or hemodialysis. $J$ Chin Med Assoc. 2005; 68:566-70. doi: 10.1016/s1726-4901(09)70095-4.

23. KALANTAR-ZADEH K; ABOTT KC, SALAHUDEEN AK, KILPATRIC RD, HORWICH TB. Survival advantages of obesity in dialysis patients. Am J Clin Nutr 2005; 81: 543-84. doi: 10.1093/ajcn/81.3.543

24. KALANTAR-ZADEH K,STREJA E, MOLNAR MZ, LUKOWSKY LR, KRISHNAN M et al. Mortality prediction by surrogates of body composition: an examination of the obesity paradox in hemodialysis patients using composite ranking score analysis. Am J Epidemiol. 2012; 175(8):793-803. doi 10.1093/aje/kwr384

25. BIAN X, LIU N, BAI Y, ZHENG L, HE P et al. Association of leptin with mortality in patients on maintenance hemodialysis IJKD 2014;8(4):314-20. PMID: 25001138.

Received $9^{\text {th }}$ November 2020 